\title{
Odynophagia after Upper Endoscopy: Uvular Necrosis
}

\author{
Runa D Watkins*, Dana Hong and Samra Blanchard \\ Department of Pediatric Gastroenterology \& Nutrition, University of Maryland, USA
}

Submission: January 19, 2017; Published: January 25, 2018

*Corresponding author: Runa D Watkins, Department of Pediatric Gastroenterology \& Nutrition, University of Maryland, Baltimore, Maryland 21201, USA, Email: rwatkins@peds.umaryland.edu

\section{Case Report}

An 8 year old female with DM1 and Celiac Disease underwent an esophagogastroduodenoscopy (EGD) to follow up for mucosal healing on a gluten free diet and presented with throat pain after the procedure. No complications were noted during the procedure, with exception of increased secretions, requiring suctioning at bedside after completion of the procedure. She noted odynophagia the next day with no fever, vomiting or abdominal pain. There was no dyspnea or other respiratory concerns, but parents did note a change in her voice after the endoscopy. She was treated with Acetaminophen, topical throat sprays and swish/spit mixture of Diphenhydramine and Maalox without improvement. Evaluation by ENT showed an ulceration of the distal uvula with no surrounding oropharyngeal edema and was diagnosed with necrosis of uvula (Figure 1). She was treated with topical Lidocaine and Tylenol. She had gradual improvement over the following week after the dependent portion of the uvula was sloughed off.

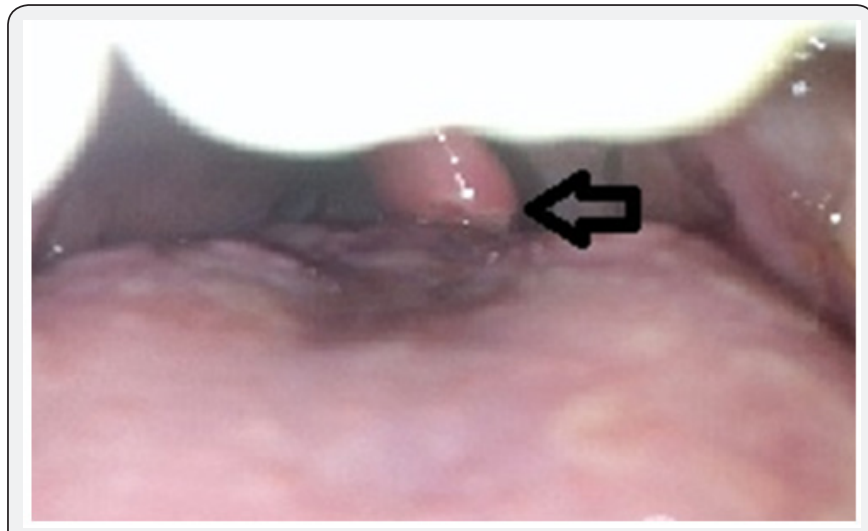

Figure 1: An ulceration of the distal uvula with no surrounding oropharyngeal edema and was diagnosed with necrosis of uvula.
Uvular necrosis is a rare complication that can occur after an EGD, direct laryngoscopy or aggressive oral suctioning. The mechanism of injury is thought to be due to ischemia, from impingement of the uvula by the instrument against the hard palate or posterior pharynx [1]. Sore throat after tracheal intubation is a common event with an incidence between 24 and $100 \%$. A recent prospective evaluation of 809 patients found it to occur in $40 \%$ with an average duration of $16 \pm 11$ hours postoperative. However, a very severe or persistent sore throat is much rarer and in these cases, uvula necrosis should be part of the differential diagnosis especially with worsening oropharyngeal pain and foreign body sensation [2-4].

Ulcerations can lead to airway compromise, bleeding or sepsis, but resolution of symptoms occurs within 5-14 days. We recommend conservative management with analgesia. The uvula regains its normal appearance and these patients have good clinical outcomes [5]. Rarely, severe cases require parenteral antibiotics and steroids.

\section{References}

1. Shores NJ, Bloomfeld RS (2009) Uvular Necrosis after Endoscopy. N Engl J Med 361: e20.

2. Arigliani M, Dolcemascolo V, Passone E, Vergine M, Cogo P (2016) Uvular trauma after laryngeal mask airway use. J Pediatr 176: 217.

3. Atkinson CJ, Rangasami J (2006) Uvula necrosis-an unusual cause of severe postoperative sore throat. Br J Anaesth 97(3): 426-427.

4. Biro P, Seifert B, Pasch T (2005) Complaints of sore throat after tracheal intubation: a prospective evaluation. Eur J Anaesthesiol 22(4): 307-311.

5. Tang Sj, Kanwal F, Gralnek IM (2000) Uvular necrosis after upper endocopy: a case report and review of the literature. Endoscopy 34(7): 585-587. 
This work is licensed under Creative (1) Commons Attribution 4.0 Licens

\section{Your next submission with Juniper Publishers will reach you the below assets}

- Quality Editorial service

- Swift Peer Review

- Reprints availability

- E-prints Service

- Manuscript Podcast for convenient understanding

- Global attainment for your research

- Manuscript accessibility in different formats ( Pdf, E-pub, Full Text, Audio)

- Unceasing customer service

Track the below URL for one-step submission https://juniperpublishers.com/online-submission.php 